\title{
Bouke Spoelstra: 'n blyk van waardering
}

\author{
C.F.A. Borchardt
}

President

Kerkhistoriese Werkgemeenskap van SA

Hiermee wil ons Bouke Spoelstra se aandeel aan die werksaamhede van die Kerkhistoriese Werkgemeenskap van Suider-Afrika in oënskou neem. Een van die voordele van die stigting van die Kerkhistoriese Werkgemeenskap op 1 Oktober 1970 was dat waar ons mekaar tevore uit geskrifte geken het, ons nou persoonlik kennisgemaak het. So het die naam Bouke Spoelstra, bekend uit sy geskrifte, veral sy proefskrif Die Doppers in Suld-Afrika (1760-1899) en sy aandeel aan die Handleiding by die Kerkorde, nou vir ons 'n gesig gekry en het hy vanweë ons jaarlikse kontak by die byeenkomste 'n gewaardeerde vriend geword. Hy het weldeeglik van homself laat hoor gedurende die twee en twintigjarige bestaan van die Werkgemeenskap en altyd waardevolle bydraes gelewer tot die bespreking van die voordragte en beplanning van die werksaamhede van die Werkgemeenskap.

Ook het hy homself deeglik rekenskap gegee van die ensiklopediese plek van die dissiplines waarmee hy besig was. So het hy in 1971 'n voordrag gehou oor die verhouding tussen Kerkgeskiedenis en Sendinggeskiedenis, en presies twintig jaar later het hy 'n voordrag gehou oor die ensiklopediese plek van Kerkreg en Praktiese Teologie. Ons kan sê dat albei dié temas vir hom uit die praktyk van sy leeropdrag gekom het, want in 1971 was hy gemoeid met die teologiese opleiding by Hammanskraal en vanaf 1991 aan die Teologiese Skool te Potchefstroom in die Departement Diakoniologie. In albei die genoemde voordragte oor die verhouding tussen Kerkgeskiedenis en Sendinggeskiedenis het hy indringend op die onderwerp ingegaan en sy hoorders en lesers geprikkel tot nadenke oor die saak.

Ook op die gebied van Kerkreg het hy belangrike bydraes gelewer. By ons byeenkoms in 1977 het hy deeglik ingegaan op die onderwerp van "Die gesag van die sinode". Hy het daarop gewys dat die idee van 'n kerkvergadering, konsilie en sinode eerder uit die invloed van die Romeinse regsdenke en polities-maatskaplike praktyke opgekom het Sy gevolgtrekking was dat die sinode

'n gebeure en geleentheid in die kerk (is) waar organe wat Christus gebruik om sy gesag te bedien, met mekaar moet en kan besig wees om tot 'n besluit te geraak waarvan gesê kan word dat dit gesag dra omdat dit met die Woord en Gees van Christus, die regering van God. ooreenkom. In ander sake 
moet hulle versigtig wees, soveel moontlik aan die persoonlike en plaaslike vryhede oorlaat en nooit gewetens bind met besluite wat nie op die Skrif steun nie ... Die gesag rus nie op die orgaan wat besluit of beveel nie. Die gesag kom nie soos wêreldlike gesag uit die 'amp' of posisie op nie. Die gesag van 'n sinode lê $m$.i. in die kwaliteit van sy besluit of bevel, in die geloofwaardigheidsevidensie dat dit kennelik 'n bediening, 'n deurgee van, 'n versorging met die gesag van Christus en die wil van God is (Studia Hist. Eccl., III 16).

Tydens die vergadering van 1984 is die tema "Calvyn en die kerkreg" behandel. Bouke het die invloed van Calvyn op die kerkordes in Suid-Afrika vanaf 16521983 behandel. Hy het gekyk na die kerkordes wat in die Nederduitse Gereformeerde Kerk, die Nederduitsch Hervormde Kerk en die Gereformeerde Kerke van Suid-Afrika gebruik was, asook in kerkordes met 'n Engelse agtergrond. Dit was 'n prikkelende voordrag en het tot heelwat diskussie aanleiding gegee. Konsensus by almal in Suid-Afrika oor dié sake sal nie maklik bereik word nie, maar enigeen wat in hierdie rigting navorsing wil doen, sal van Spoelstra se goedgefundeerde artikel kennis moet neem.

By die byeenkoms van die Werkgemeenskap in 1981 het Spoelstra 'n belangrike bydrae gelewer met sy voordrag oor "Die Gereformeerde Ekumeniese Sinode". Hy het breedvoerig op alle aspekte van die GES ingegaan, onder andere sy gesag en karakter en sy verhouding tot die Gereformeerde Kerke van Nederland. As iemand wat nou by die vergaderings van die beweging betrokke was en die werking van binne meegemaak het, het ons kongresgangers 'n gesaghebbende mening oor die GES gekry. Intussen is dit geskiedenis dat van sy kritiese vrae bewaarheid is en ons weet waar die GES (GER) vandag staan

Bouke het by ' $n$ hele paar kongresse belangrike bydraes gelewer deur response wat hy op voordragte moes lewer. Die onderwerpe was uiteenlopend, maar het sy groot kennis van en liefde vir die kerkgeskiedenis geillustreer. Sy bydraes was altyd weldeurdag. Hy het sterk en sonder ekskuus sy standpunt gestel maar 'n mens het altyd gevoel dat hy ook aan ander ruimte gelaat het om hulle beskouings te stel. Sy optrede was in 'n ekumeniese en verdraagsame gees. By ons byeenkoms gedurende 1991 was daar probleme rondom 'n meer verteenwoordigende lidmaatskap en toe daar 'n komitee aangewys is om die saak te ondersoek en 'n pad vorentoe aan te wys, was Bouke onder diegene wat ons by die volgende vergadering van raad moes bedien. Sy verstandige raad het ook in hierdie aangeleentheid goed te pas gekom.

Bouke Spoelstra het deur die jare bewys gelewer van deeglike navorsing, groot kundigheid, oorwoë bevindinge in sy werk en groot wysheid in die praktyk. Ons is dankbaar vir sy groot bydrae tot ons werksaamhede en hoop dat die Here hom nog lank vir ons as Werksgemeenskap sal spaar. 